\title{
In Vitro Culture Techniques from Cotyledon Explants of Celastrus Paiculatus (Wild) a Medicinal Important Plant
}

\section{Mandaloju Venkateshwarlu}

\author{
M.Sc, Ph.D Botany, M.Sc. BioTechenology, FHAS, SFS,SFAB,CFE, AND ( LLB), Department of Botany, Kakatiya University, \\ Warangal - 506 oog, Telangana, India.
}

\section{(c) (i) (8)}

Copyright@IJCRR

Cytokinins were found to influence cell growth by promoting nucleic acid metabolism and the synthesis of specific proteins required for cell division. It was further reported that cytokinins bind to a specific receptor site in the cell to bring about organogenesis. Physical environment viz., state of medium, light, temperature, humidity etc., besides source and size of explants are known to play an important role in the in vitro Organogenesis. ${ }^{1}$ The explants cultured on regeneration media fortified with different vitamins, auxins and cytokinins (BAP, Kinetin) in the concentrations of 0.5 and $3.0 \mathrm{mg} / \mathrm{l}$. Cell maintain in vitro undergo a certain level of spontaneous genetic change, which may be induced or expressed by culture conditions. ${ }^{6}$ Variant cells may be induced to generate. Seedling was grown in vitro from sterilized seeds on the MS basal medium and explants like cotyledons.

One of the regenerates showed some variation in the morphology of leaves which led to the estimation of morphological changes quantity of the fruits of regenerant in order to detect any variants between the control, the normal regenerates and variant obtained. Impact of various growth regulators on tissue and isolated plant cells was studied by several workers and these substances were known to play an important role in cell metabolism, cell membrane synthesis ${ }^{2,4}$ besides growth and differentiation, ${ }^{14}$ of these growth substances auxins have proved to be an essential supplement for establishing successful culture of plant tissues. ${ }^{5}$ Auxins were found to exert their hormonal action through their effects on the nucleic acids and protein metabolism. It also found that auxinsaxert their effects, directly or indirectly on 'S' phase of DNA synthesis.

Key Words: In Vitro Techniques, Cotyledon culture, Celastruspaniculatus, Cell metabolism, Cell membrane synthesis, Growth and differentiation

\section{INTRODUCTION}

This phenomenon is called oxidative stress and is known as one of the major causes of plant damage as a result of environmental stresses ${ }^{15}$ one that produces the transcription factor in 10 times higher amounts than normal plants and another that does not produce it at all. It turned out that the plants with the elevated production of the HsFA1 showed increased resistant to heat stress and the plants without any transcription factor sustained severe damage. ${ }^{16,7}$ In general, coconut water reduces the amount of 2, 4-D, required to for initiation and growth of callus and it is well known that 2, 4-D, levels had pronounced effect on callus initiation in sugarcane explants. ${ }^{8}$ Recent developments in molecular biology and genetic transformation however, have made it possible to identify, isolate and transfer desirable genes in to sugarcane. ${ }^{17} \mathrm{In}$ dryland agriculture, the altered plants showed increased pro- duction. ${ }^{12}$ Most of the recent research was made on Tobacco, Alfalfa and Arabidopsis thaliana.,

\section{MATERIAL AND METHODS}

The explants (Cytoledons) were harvested and washed with distilled water. The explants were surface sterilized in laminar airflow hood by sequentially washing them with $5 \%$ Sodium hydrochloride containing 2-3 drops of tween 20 for 7-10 min. The explants were rinsed thrice with sterile distilled water after each sterilant for 3-5 min. the explants were harvested and dipped in water until used. Each of these MS Media contained entire sucrose as the other components these inoculated cotylednary explants were monitored regularly for induction of micro shoots. The explants which increased at least a single micro shoot was scored as

\section{Corresponding Author:}

Dr. Mandaloju Venkateshwarlu, M.Sc, Ph.D Botany, M.Sc. BioTechenology, FHAS, SFS,SFAB,CFE, AND ( LLB), Department of Botany, Kakatiya University, Warangal - 506 009, Telangana, India; Email: drvenkat6666@gmail.com

ISSN: 2231-2196 (Print)

Received: 08.11 .2021
ISSN: 0975-5241 (Online)

Revised: 22.11 .2021
Accepted: 14.12 .2021
Published: 01.02 .2022 
responding explants. Among the three concentration used, $15 \%$ of coconut milk along with $0.5 \mathrm{mg} / 1 \mathrm{BAP}$ has proved to be ideal for multiple shoot induction MS medium fortified with $1.0 \mathrm{mg} / 1 \mathrm{BAP}$ and $2.0 \mathrm{mg} / \mathrm{l} \mathrm{L}-$ Glutamic acid favored the induction of multiple shoots which ranged from 8-10 from cotyledon segments. Tissue culture techniques have been widely used as an alternative for large scale micropropagation and can effectively reduced the time period between selection and commercial release of new sugarcane varieties. ${ }^{11}$ Explants preparation for callus initiation was done as per the protocol followed by ${ }^{13,10}$ The cotyledon explants inoculated on MS medium containing BAP and 2, 4-D initiated callus. Addition of NAA and BAP to the MS medium resulted in a small bud formation from callus derived from cotyledon. MS medium supplemented with $10 \%, 15 \%$ and $20 \%$ of coconut milk in addition to cytokinin (BAP) triggered the induction of multiple shoots.

\section{RESULTS}

The present observations of the explants were collected from field grown plants thought out the year to determine the ideal season for culture established. The shoots obtained were rooted, when placed on media containing $2.0 \mathrm{mg} / \mathrm{l} \mathrm{NAA}+5$ $\mathrm{mg} / \mathrm{L} \mathrm{BAP}$, resulting in the formation of plantlets with roots containing drained soil, and were covered with polythene bags 20 days in a growth chamber, in order to harden the potted plants. Well-developed plantlets were transferred to earthen pots (Table 1, Figure 1A-Callus). Celastruspaniculatuscotyledon explants were inoculated on MS basal medium fortified with various Cytokinins i.e, BAP and Kinetin. Coconut water also had a role in triggering the formation of multiple shoots(Figure 1B). Among all the explants used, segments were the best for multiple shoot induction (Figure 1C) followed by the cotyledon. Well-developed multiple shoots obtained, were carefully isolated into individual segments along with a node each, and were placed on rooting medium.

\section{DISCUSSION}

Culturing the microshoots for an extended period by repeatedly sub-culturing them over the same media which induced them increased the frequency of elongation to $50 \%$. However this attempt also could not elongate the microshoots longer then 2-4 shoots. We also attempted to elongate the microshoots over the media with reduced agar content. The effectiveness of MS medium in inducing regeneration in the Cotyledon explants.

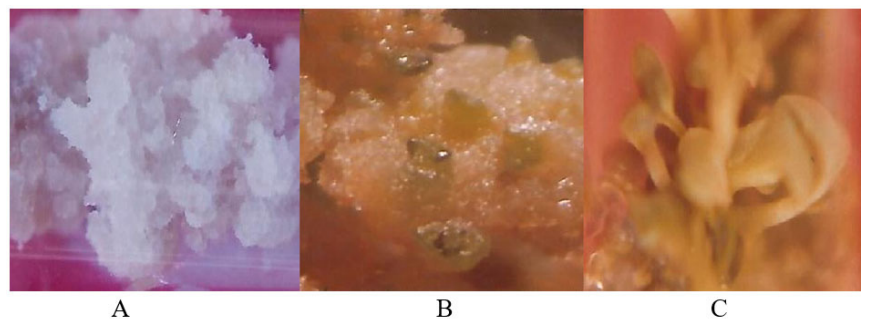

Figure I: In Vitro Culture Techniques From Cotyledon Explants Of CelastrusPaiculatus. (Figure A. Callus, Figure B.Sub Culture, Figure C. Regeneration Plantlets).

Table 1: In Vitro Culture Techniques From Cotyledon Explants of CelastrusPaiculatus.

$\begin{array}{lll}\text { S. No. } & \text { Growth Regulators } & \text { Cotyledon Explants } \\ 1 & \text { BAP + Kinetin } 0.5 \mathrm{mg} / \mathrm{l}+\mathrm{IAA} & \text { Callus } \\ 2 & \text { BAP + Kinetin } 1.5 \mathrm{mg} / \mathrm{l}+\mathrm{IAA} & \text { Green Callus } \\ 3 & \text { BAP + Kinetin } 2.0 \mathrm{mg} / \mathrm{l}+\mathrm{IAA} & \begin{array}{l}\text { Sub Culture with } \\ \text { small shoot buds } \\ \text { Yellow Callus with } \\ \text { smallshoot } \\ \text { buds }\end{array} \\ 4 & \begin{array}{l}\text { BAP + Kinetin + 2.5mg/l-L } \\ \text { Gutamic acid }\end{array} & \begin{array}{l}\text { BAP + Kinetin + 3.0 mg/l L- } \\ \text { Gutamic acid }\end{array} \\ 5\end{array}$

\section{CONCLUSION}

The Cotyledon explants became active within 4-6 weeks after inoculation and new shoots become distinct by the fourth week with leaves and internodes. The explants were collected from field-grown plants thought out the year. Addition of $3.0 \mathrm{mg} / 1 \mathrm{BAP}$ or $5.0 \mathrm{mg} / 1$ Kinetin the MS medium induced shoot regeneration from the cultures and the proximal end of auxiliary region of cotyledon explants. Within a period of two weeks in culture. With an increase in the level of BAP $(2.0-4.0 \mathrm{mg} / \mathrm{l})$ the percentage of and cotyledon explants producing shoots also increased. We were successful in cotylean cultures, resected in better yield of fairly good when above maintained condition. MS medium supplemented with BAP and IAA initiated formation of callus from leaf culture. Addition of kinetin along with L-Glutamic acid and $15 \%$ coconut milk induced multiple shoots from callus cotyledon explants.

\section{ACKNOWLEDGMENT}

I am grateful to the Head and Staff Department of Botany E2 POT Final year students UC, KU for providing the Laboratory facilities.

Source of funding: SERO Hyd, TS India. 
Conflict of Interest: In Vitro Development of regeneration of whole plant through tissue culture.

Authors' Contribution: Initiated form a single explant taken from any living part of an explant and within very short time and space a larger number of plantlets can be produced from callus tissues.

\section{REFERENCES}

1. Benarjee R, Gouswami P, Lavania S, Mukherjee A and Lavania UC. Vetiver grass is a potential Candidate for phytoremediation of iron ore mine spoil dumps. Ecological Engineering (2019) Vol.132: PP120-136.

2. Cocking E.C. Selection and somatic hybridization in Frontiers of plant tissue culture (ed) T.A. Thrope, Academic press. (1978) PP. 151-158.

3. Datta S.K. Recent developments in transgenics for abiotic stress tolerance in rice JIRCAS working Report. (2002) Vol. 23: PP 43-46.

4. Gago J, Martinez-Nunez L, Landin M, Flexas J and Gallego PP Modelling the effects of light and sucrose on in vitro propagated plants. A multiple system analysis using artificial intelligence technology (2014) PLOS ONE Vol. 09: PP 1-11.

5. GantherectR.J.Thenutritionofplanttissuecultures.Ann.Rev.Plant. Physiol.(1995)Vol.6:PP 433-484.

6. Gauchan DP Effect of different sugars on shoot regeneration of maize ( Zia mays L ) Katmandu University Journal of Science and Engineering Tech (KUSET) (2012) Vol. 8: PP119-124.

7. Gyves E, Royani JI and Rugini E Efficient method of micropropagation and in vitro rooting of teak (Tectonagrandis L) focusing on large scale industrial plantations. Animal of Forest Sci. (2007) Vol. 64:PP 73-78.
8. Kell DB. Large Scale sequestration of atmospheric Carbon via plant roots in natural and agricultural ecosystems why and how phil Trans. R. Soc.B. (2012) Vol. 367: PP 1589-1597.

9. Lavania UC and Lavania S. Sequestration of atmospheric carbon into subsoil horizons through deep-rooted grasses-vetiver grass model. Curr.sci (2009) Vol. 97: PP 618-619.

10. Lavania S Descriptors for vetivervetiversim 21: 5-10. Hughes $\mathrm{EH}$, Shanks JV Metabalic engineering of plants for alkaloid production. Metabolic Engineering V. (2002) Vol. 4 PP 41- 48.

11. Lorenzo J.C, Ojeda E, Espinosa A and Borrotoc A. Field performance of temporary immersion Bioreacter- Derived sugarcane plants. In vitro callus Dev. Bio plant. (2001) Vol. 37: PP 803806.

12. Moffat A.S. Finding new ways to protected rough stricken plants. Science (2002) 117: 1226-1229.

13. Santhosha D.A, Roy H, Farrouk A and Greiner R. A rapid and highly efficient method for transformation of sugarcane callus. Molecular Biotechnology(2004) Vol. 28: PP 113-119.

14. Smith and Smet ID Roof system architecture insights from Arabidopsis and cereal crops. Phil. Trans. R. Soc. B (2012) Vol. 367, PP 1441-1452.

15. Street H.E. Growth in organized and unorganized systems. Knowledge gained by culture of organs and tissue explants. In: Plant physiology treatise (e). F.C. Steward, Academic Press, New York. (1969) Vol. 5: PP 213-224.

16. Sunkar R, Bartels D and Kirch H.H. Over expression of a stress sucible dehydrogenase gene from Arabidopsis thaliangin transgenic plants improves stress tolerance. The plant Journal (2003) Vol. 35(4): PP 452.

17. Wantner R. Stress bewaltingungbeitomaten, FA2 (Feuilletou) 15 Juli Nr (2002) Vol. 136: PP 48.

18. Yamada T, Sakiya I and Kobhimizn K. Cytokinin induced shoot formation phytochemistry: (1972) Vol. 11: PP 1019-1021. 